\title{
Mucilaginibacter paludis gen. nov., sp. nov. and Mucilaginibacter gracilis sp. nov., pectin-, xylan- and laminarin-degrading members of the family Sphingobacteriaceae from acidic Sphagnum peat bog
}

\author{
Timofei A. Pankratov, ${ }^{1}$ Brian J. Tindall, ${ }^{2}$ Werner Liesack $^{3}$ \\ and Svetlana N. Dedysh ${ }^{1}$ \\ ${ }^{1}$ S. N. Winogradsky Institute of Microbiology, Russian Academy of Sciences, Prospect 60-letya \\ Octyabrya 7/2, Moscow 117312, Russia \\ ${ }^{2}$ DSMZ - German Collection of Microorganisms and Cell Cultures, D-38124 Braunschweig, \\ Germany \\ ${ }^{3}$ Max-Planck-Institut für terrestrische Mikrobiologie, D-35043 Marburg, Germany
}

Correspondence

Svetlana N. Dedysh dedysh@mail.ru
Two facultatively aerobic, heterotrophic bacteria capable of degrading pectin, xylan, laminarin and some other polysaccharides were obtained from the acidic Sphagnum peat bog Bakchar, in western Siberia, Russia, and were designated strains TPT18 ${ }^{\top}$ and TPT56 ${ }^{\top}$. Cells of these isolates are Gram-negative, non-motile, long rods that are covered by large capsules. On ageing, they transform into spherical L-forms. Strains TPT $18^{\top}$ and TPT5 $6^{\top}$ are acido- and psychrotolerant organisms capable of growth at $\mathrm{pH} 4.2-8.2$ (with an optimum at $\mathrm{pH} 6.0-6.5$ ) and at $2-33^{\circ} \mathrm{C}$ (with an optimum at $20^{\circ} \mathrm{C}$ ). The major fatty acids are iso- $\mathrm{C}_{15: 0}$, anteiso- $\mathrm{C}_{15: 0}$, iso- $\mathrm{C}_{17: 0} 3-\mathrm{OH}$ and summed feature 3 (iso- $\mathrm{C}_{15: 0} 2-\mathrm{OH}$ and/or $\mathrm{C}_{16: 1} \omega 7 \mathrm{c}$ ); the quinones are MK-7 and MK-6. Comparative 16S rRNA gene sequence analysis revealed that the novel strains share $97 \%$ sequence similarity and belong to the family Sphingobacteriaceae; however, they are related only distantly to members of the genera Pedobacter (91.8-93.3\% similarity) and Sphingobacterium (89.6-91.2\% similarity). The DNA G $+C$ content of strains TPT1 $^{\top}$ and TPT56 $^{\top}$ is 42.4 and $46.1 \mathrm{~mol} \%$, respectively. The low DNA-DNA hybridization value $(42 \%)$ and a number of phenotypic differences between strains TPT $18^{\top}$ and $\mathrm{TPT}^{2} 6^{\top}$ indicated that they represent two separate species. Since the two isolates are clearly distinct from all currently described members of the family Sphingobacteriaceae, we propose a novel genus, Mucilaginibacter gen. nov., containing two novel species, Mucilaginibacter gracilis sp. nov. and Mucilaginibacter paludis sp. nov. The type strains of Mucilaginibacter gracilis and Mucilaginibacter paludis are respectively

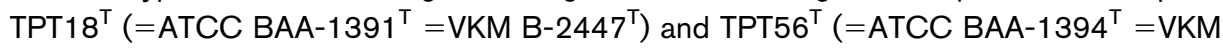
$\left.B-2446^{\top}\right)$.
Representatives of the phylum Bacteroidetes are widely distributed in aquatic and terrestrial habitats and are especially proficient in degrading various biopolymers. These bacteria comprise a significant portion of the isolates obtained routinely from water and soil samples and are reasonably well represented in culture collections (Floyd

Abbreviation: EPS, extracellular polymeric substance.

The GenBank/EMBL/DDBJ accession numbers for the 16S rRNA gene sequences of Mucilaginibacter gracilis TPT $18^{\top}$ and M. paludis TPT56 ${ }^{\top}$ are AM490402 and AM490403.

Detailed phenotypic characteristics of strains TPT $18^{\top}$ and TPT56 ${ }^{\top}$ are available as supplementary material with the online version of this paper. et al., 2005). However, in contrast to many other environments, little is known about members of the Bacteroidetes that inhabit acidic Sphagnum peat bogs. So far, taxonomically characterized members of the Bacteroidetes from this acidic habitat are represented by only four strains of gliding, xylanolytic and laminarinolytic bacteria that were identified as Chitinophaga arvensicola (Pankratov et al., 2006). Here, we describe two more polysaccharidedegrading representatives of the phylum Bacteroidetes from acidic peat.

Strains TPT $18^{\mathrm{T}}$ and $\mathrm{TPT}^{2} 6^{\mathrm{T}}$ were isolated from a sample collected from $10-20 \mathrm{~cm}$ below the surface of the Sphagnum peat bog Bakchar, in the Tomsk region of 
western Siberia $\left(56^{\circ} 51^{\prime} \mathrm{N} 82^{\circ} 50^{\prime} \mathrm{E}\right)$, by spread-plating of serially diluted peat suspension onto the surface of peat extract medium solidified with gellan gum (a polysaccharide from Alteromonas sp.; Fluka) (Dedysh et al., 2006). Two highly distinctive types of either cream- or pink-coloured, raised, semi-transparent and slimy colonies developed on plates inoculated with the terminal dilutions of peat suspension. Both types of colonies were composed of rod-shaped bacteria that produced large amounts of an extracellular polymeric substance (EPS). Partial sequencing of the 16S rRNA genes from these two bacteria showed that they are affiliated with the Bacteroidetes and are only distantly related (89-91\% sequence similarity) to members of the genera Pedobacter and Sphingobacterium. Thus, the goal of our study was to determine the taxonomic position of the newly isolated strains and to examine their capacity to degrade various biopolymers under acidic conditions.

The isolates were maintained on tenfold-diluted agar medium R2A (Difco). All tests were carried out using medium MM1 containing ( $1^{-1}$ distilled water) $0.5 \mathrm{~g}$ glucose, $0.04 \mathrm{~g} \mathrm{MgSO}_{4} .7 \mathrm{H}_{2} \mathrm{O}, 0.02 \mathrm{~g} \mathrm{CaCl}_{2} .2 \mathrm{H}_{2} \mathrm{O}$ and $0.1 \mathrm{~g}$ yeast extract. Cell morphology and cell life cycle were examined using cultures grown on agar medium MM1. Preparation of ultrathin sections was performed as described before (Kulichevskaya et al., 2006). Growth of the novel strains under a variety of conditions, including temperatures of $2-37{ }^{\circ} \mathrm{C}, \mathrm{pH} 4.0-9.0$ and $\mathrm{NaCl}$ concentrations of $0.01-3.0 \%(\mathrm{w} / \mathrm{v})$, was examined using batch cultures grown in liquid medium MM1. The $\mathrm{OD}_{600}$ was measured in an Eppendorf BioPhotometer at 2 day intervals for 2 weeks. The range of potential growth substrates of the novel strains was examined by replacing glucose in medium MM1 with various carbon sources. The ability to degrade different biopolymers was examined by measuring the rate of $\mathrm{CO}_{2}$ production in tightly closed $120 \mathrm{ml}$ serum bottles containing $20 \mathrm{ml}$ liquid medium MM1 with $0.05 \%(\mathrm{w} / \mathrm{v})$ of the corresponding polymer substrate for 1 month at $20{ }^{\circ} \mathrm{C}$. Control incubations were run in parallel under the same conditions but without substrate. Fermentative utilization of carbohydrates was investigated as described for the Hugh-Leifson test (Gerhardt et al., 1981). Susceptibility to antibiotics was determined on MM1 agar plates using discs (Oxoid) containing the following antibiotics: ampicillin $(10 \mu \mathrm{g})$, gentamicin $(10 \mu \mathrm{g})$, kanamycin $(30 \mu \mathrm{g})$, neomycin $(10 \mu \mathrm{g})$, novobiocin $(30 \mu \mathrm{g})$, streptomycin $(10 \mu \mathrm{g})$, chlorampheni$\mathrm{col}(30 \mu \mathrm{g})$ and lincomycin $(10 \mu \mathrm{g})$.

Cell biomass for cellular fatty acid and isoprenoid quinone analyses and for DNA extraction was obtained from batch cultures grown in liquid MM1 medium at $24{ }^{\circ} \mathrm{C}$ for 1 week. Cellular fatty acid analysis was performed by the DSMZ Identification Service. Isoprenoid quinones were extracted according to Collins (1985) and analysed using an LCQ ADVANTAGE MAX tandem-type mass spectrometer and a Finnigan Mat 8430 ionization mass spectrometer. The DNA base composition of strains was determined by thermal denaturation using a Unicam
SP1800 spectrophotometer at a heating rate of $0.5{ }^{\circ} \mathrm{C}$ $\min ^{-1}$. The $\mathrm{G}+\mathrm{C}$ content was calculated according to Owen et al. (1969). PCR-mediated amplification of the $16 \mathrm{~S}$ rRNA gene was performed using primers $9 \mathrm{f}$ and 1492r and reaction conditions described by Weisburg et al. (1991). 16S rRNA gene amplicons were purified using QIAquick spin columns (Qiagen) and sequenced on an ABI Prism 377 DNA sequencer (PE Applied Biosystems). Phylogenetic analysis was carried out using the ARB program package (Ludwig et al., 2004).

On solid media made with agar or gellan gum, strains $\mathrm{TPT}_{18}{ }^{\mathrm{T}}$ and $\mathrm{TPT}^{\mathrm{T}}{ }^{\mathrm{T}}$ formed large (up to $1 \mathrm{~cm}$ in diameter), convex, circular, semi-transparent colonies of slimy consistency. The colony colour varied from cream to light orange for strain TPT $18^{\mathrm{T}}$ and from light pink to reddish for strain $\mathrm{TPT}^{\mathrm{T}} 6^{\mathrm{T}}$. Cells of these strains were Gram-negative, non-spore-forming, non-motile rods that occurred singly, in pairs or in short chains and were covered with large capsules of EPS. Young (2-3 days old) cultures contained long cells $(6-15 \mu \mathrm{m})$ (Fig. 1a, b); cells up to $40 \mu \mathrm{m}$ in length were occasionally observed. On ageing, long cells divided by binary fission into several nonmotile shorter $(1.5-5 \mu \mathrm{m})$ cells. Cells of strain TPT $56^{\mathrm{T}}$ were slightly thicker $(0.5-0.8 \mu \mathrm{m})$ than cells of strain $\mathrm{TPT}_{18}{ }^{\mathrm{T}}(0.4-0.5 \mu \mathrm{m})$. Old cultures of both strains contained L-forms of cells (Fig. 1c). Morphologically, the L-forms appeared as spherical bodies of varying sizes (0.5$3 \mu \mathrm{m})$; some of them were granular and some contained vacuoles (Fig. 1d). After transfer to fresh medium, the Lforms reverted to normal vegetative cells that continued to grow as usual. Ultrathin sections of vegetative cells revealed the presence of numerous spherical outer-membrane vesicles, ranging in size from 50 to $240 \mathrm{~nm}$ (Fig. 1e, f). Also, small globular bodies bounded by bilayered membranes and resembling mesosome-like structures were observed in many cells of the novel isolates (Fig. 1e, f). The nature of these cell structures remains unclear.

The novel isolates from Sphagnum peat had an absolute requirement for the presence of growth factors (50-100 mg yeast extract $1^{-1}$ ) in cultivation media. Thus, utilization of a given carbon compound was assumed to have occurred when growth was distinctly improved in its presence compared with basal MM1 medium alone. The carbon compounds tested and the results are given in the two species descriptions (see below) or are shown in Supplementary Table S1 (available in IJSEM Online). Sugars were the preferred growth substrates. Strain TPT $18^{\mathrm{T}}$ differed from strain TPT $^{2} 6^{\mathrm{T}}$ in its ability to utilize Darabinose, D-raffinose and salicin and its inability to utilize myo-inositol and $\mathrm{N}$-acetylglucosamine. Both novel isolates were able to hydrolyse pectin, laminarin, xylan, chondroitin sulfate, gellan gum, pullulan and starch.

Strains $\mathrm{TPT}_{18}{ }^{\mathrm{T}}$ and $\mathrm{TPT} 56^{\mathrm{T}}$ grew in the $\mathrm{pH}$ range $4.2-8.2$, with an optimum at $\mathrm{pH} 6.0-6.5$. The temperature range for growth was $2-33{ }^{\circ} \mathrm{C}$, with an optimum at $20{ }^{\circ} \mathrm{C}$. Growth was inhibited completely at $\mathrm{NaCl}$ concentrations 

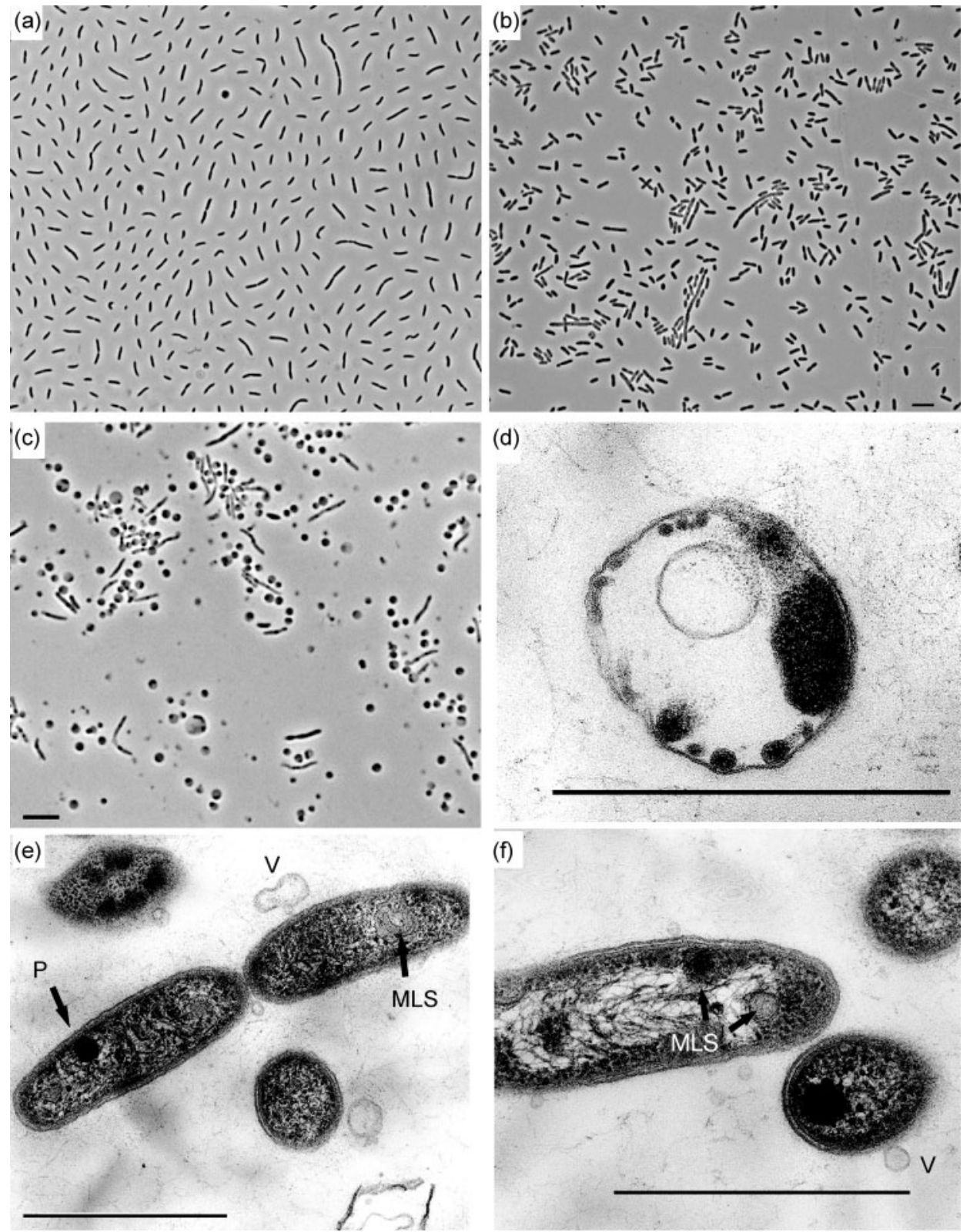

Fig. 1. (a-c) Phase-contrast micrographs of cells of strains $\mathrm{TPT} 18^{\top}$ (a) and TPT56 ${ }^{\top}$ (b) grown on MM1 medium for 3 days and L-forms of cells in a 2-week-old culture of strain TPT18 ${ }^{\top}(c) .(d-f)$ Electron micrographs of ultrathin sections of vegetative cells (e, f) and an L-form of a cell (d) of strain TPT56 ${ }^{\top}$. V, Outer-membrane vesicles; MLS, mesosome-like structures; P, polyphosphate granules. Bars, $5 \mu \mathrm{m}$ [b (also applies to a), c] and $1 \mu \mathrm{m}$ (d-f).

above $1.0 \%(\mathrm{w} / \mathrm{v})$. Both strains were resistant to ampicillin, gentamicin, kanamycin, neomycin and novobiocin and susceptible to streptomycin. Strain TPT $18^{\mathrm{T}}$ differed from strain $\mathrm{TPT}^{\mathrm{T}} 6^{\mathrm{T}}$ in its susceptibility to lincomycin and resistance to chloramphenicol.

Both novel isolates contained menaquinone-7 (MK-7) as the predominant isoprenoid quinone and MK-6 as a minor component. The cellular fatty acid profiles of strains
TPT $18^{\mathrm{T}}$ and $\mathrm{TPT} 56^{\mathrm{T}}$ had significant similarity to those of members of the family Sphingobacteriaceae. Similar to representatives of the genera Pedobacter and Sphingobacterium, the major fatty acids of the novel strains were iso$\mathrm{C}_{15: 0}$, iso- $\mathrm{C}_{17: 0}$ 3-OH, iso- $\mathrm{C}_{15: 0} \quad 2-\mathrm{OH}$ and $\mathrm{C}_{16: 1} \omega 7 c$ (Table 1). However, the cellular fatty acid profiles of the novel isolates differed from those of Pedobacter and Sphingobacterium species by the presence of significant amounts of anteiso- $\mathrm{C}_{15: 0}$ (up to $21 \%$ of the total fatty acids). 
Table 1. Cellular fatty acid compositions (\%) of strains TPT56 $^{\top}$ and TPT $18^{\top}$ and representatives of the genera Pedobacter and Sphingobacterium

Data for Pedobacter and Sphingobacterium species were taken from Steyn et al. (1998), Kim et al. (2006), Gallego et al. (2006) and Yoon et al. (2006). - , Not detected; tr, trace $(<1.0 \%)$.

\begin{tabular}{|c|c|c|c|c|}
\hline Fatty acid & TPT56 $^{\mathrm{T}}$ & TPT18 $^{\mathrm{T}}$ & Pedobacter & $\begin{array}{c}\text { Sphingobac- } \\
\text { terium }\end{array}$ \\
\hline $\mathrm{C}_{14: 0}$ & $\operatorname{tr}$ & $\operatorname{tr}$ & $\operatorname{tr}-1.6$ & $0-3.2$ \\
\hline $\mathrm{C}_{14: 0} 2-\mathrm{OH}$ & $\operatorname{tr}$ & - & - & - \\
\hline iso- $\mathrm{C}_{13: 0} 3-\mathrm{OH}$ & $\operatorname{tr}$ & $\operatorname{tr}$ & - & - \\
\hline iso- $\mathrm{C}_{15: 0}$ & 15.7 & 32.2 & $25.4-38.3$ & $17.7-45.6$ \\
\hline anteiso- $\mathrm{C}_{15: 0}$ & 21.1 & 5.8 & $\operatorname{tr}-2.9$ & $\operatorname{tr}-2.6$ \\
\hline $\mathrm{C}_{15: 1} \omega 6 c$ & $\operatorname{tr}$ & 1.2 & $\operatorname{tr}-1.4$ & - \\
\hline $\mathrm{C}_{15: 1} \omega 5 c$ & - & $\operatorname{tr}$ & - & - \\
\hline $\mathrm{C}_{15: 0}$ & 3.2 & 4.5 & $\operatorname{tr}-1.6$ & - \\
\hline iso- $\mathrm{C}_{16: 0}$ & 1.5 & $\operatorname{tr}$ & - & - \\
\hline $\mathrm{C}_{16: 1} \omega 5 c$ & 5.8 & 2.6 & $\operatorname{tr}-4.5$ & $0-1.5$ \\
\hline $\mathrm{C}_{16: 0}$ & 3.1 & $\operatorname{tr}$ & $1.1-4.0$ & $\operatorname{tr}-7.8$ \\
\hline iso- $\mathrm{C}_{15: 0} 3-\mathrm{OH}$ & 1.8 & 3.2 & $2.1-3.1$ & $1.5-4.3$ \\
\hline $\mathrm{C}_{15: 0} 2-\mathrm{OH}$ & $\operatorname{tr}$ & $\operatorname{tr}$ & - or $\operatorname{tr}$ & - \\
\hline iso- $\mathrm{C}_{17: 1} \omega 9 c$ & $\operatorname{tr}$ & 2.7 & $1.6-6.6$ & $0-3.7$ \\
\hline anteiso- $C_{17: 1} \omega 9 c$ & - & - & $0-1.2$ & - \\
\hline $\mathrm{C}_{15: 0} 3-\mathrm{OH}$ & - & $\operatorname{tr}$ & - & - \\
\hline iso- $\mathrm{C}_{17: 0}$ & $\operatorname{tr}$ & $\operatorname{tr}$ & - & - \\
\hline anteiso- $\mathrm{C}_{17: 0}$ & 4.5 & - & - & - \\
\hline $\mathrm{C}_{17: 1} \omega 8 c$ & $\operatorname{tr}$ & 1.5 & - & - \\
\hline $\mathrm{C}_{17: 1} \omega 6 c$ & $\operatorname{tr}$ & $\operatorname{tr}$ & - & - \\
\hline $\mathrm{C}_{17: 0}$ & $\operatorname{tr}$ & $\operatorname{tr}$ & - & - \\
\hline iso- $\mathrm{C}_{16: 0} 3-\mathrm{OH}$ & $\operatorname{tr}$ & $\operatorname{tr}$ & - & - \\
\hline $\mathrm{C}_{16: 0} 2-\mathrm{OH}$ & - & - & - or tr & $0-3.2$ \\
\hline $\mathrm{C}_{16: 0} 3-\mathrm{OH}$ & $\operatorname{tr}$ & $\operatorname{tr}$ & $\operatorname{tr}-4.5$ & $0-6.3$ \\
\hline iso- $\mathrm{C}_{17: 0} 3-\mathrm{OH}$ & 8.9 & 13.1 & $9.2-15.2$ & $7.1-22.1$ \\
\hline $\mathrm{C}_{17: 0} 2-\mathrm{OH}$ & $\operatorname{tr}$ & $\operatorname{tr}$ & - & - \\
\hline $\mathrm{C}_{17: 0} 3-\mathrm{OH}$ & $\operatorname{tr}$ & $\operatorname{tr}$ & - & - \\
\hline $\mathrm{C}_{18: 1} \omega 9 \mathrm{c}$ & $\operatorname{tr}$ & - & - & - \\
\hline $\mathrm{C}_{18: 0}$ & $\operatorname{tr}$ & - & - & - \\
\hline Summed feature $3^{*}$ & 24.7 & 21.5 & $21.3-46.8$ & $25.4-57.8$ \\
\hline
\end{tabular}

${ }^{\star}$ Summed feature 3 contains iso- $\mathrm{C}_{15: 0} 2-\mathrm{OH}$ and/or $\mathrm{C}_{16: 1} \omega 7 c$.

Comparative sequence analysis of the $16 \mathrm{~S}$ rRNA gene placed strains $\mathrm{TPT}^{\mathrm{T}} 8^{\mathrm{T}}$ and $\mathrm{TPT}^{\mathrm{T}}{ }^{\mathrm{T}}$ in the family Sphingobacteriaceae. However, they were only distantly related to members of the genera Pedobacter (91.8-93.3\% sequence similarity) and Sphingobacterium (89.6-91.2\% sequence similarity) (Fig. 2). The two strains shared a $16 \mathrm{~S}$ rRNA gene sequence similarity of $97 \%$. The DNA G+C content of strains $\mathrm{TPT} 18^{\mathrm{T}}$ and $\mathrm{TPT}^{\mathrm{T}} 6^{\mathrm{T}}$ was 42.4 and $46.1 \mathrm{~mol} \%$, respectively. A low DNA-DNA hybridization value $(42 \%)$ and a number of phenotypic differences between them indicated that they represent two separate species.

Since the novel isolates from Sphagnum peat possessed a number of characteristics that clearly distinguished them from the members of the genera Pedobacter and Sphingobacterium (Table 2), we propose a novel genus, Mucilaginibacter gen. nov., and two novel species, Mucilaginibacter gracilis sp. nov. and Mucilaginibacter paludis sp. nov., for strains TPT $18^{\mathrm{T}}$ and $\mathrm{TPT}^{\mathrm{T}} 6^{\mathrm{T}}$.

\section{Description of Mucilaginibacter gen. nov.}

Mucilaginibacter (Mu.ci.la'gi.ni.bac'ter. L. n. mucilago -inis mucus; N.L. masc. n. bacter rod; N.L. masc. n. Mucilaginibacter mucus-producing rod).

Gram-negative, non-spore-forming, non-motile rods that occur singly, in pairs or in short chains and produce large amounts of EPS. Cells undergo a cyclic shape change during culture development. Young cultures contain long cells $(6-15 \mu \mathrm{m}$, sometimes up to $40 \mu \mathrm{m}$ in length). On ageing, long cells divide by binary fission into several nonmotile shorter $(1.5-5 \mu \mathrm{m})$ cells. Old cultures contain Lforms of cells, which revert to normal vegetative cells after transfer to fresh medium. Cells produce numerous outermembrane vesicles. Colonies are large $(3-10 \mathrm{~mm}$ in diameter), convex, circular, semi-transparent and slimy. The colony colour on tenfold-diluted medium R2A varies from cream to light orange and reddish. Flexirubin-type pigments are absent. Oxidase- and catalase-positive. Chemo-organotrophic facultative aerobes. Sugars are the preferred growth substrates. Capable of fermenting glucose and sucrose. Cannot utilize melibiose, melezitose, cellulose, chitin, heparin or aesculin. Hydrolyse pectin, xylan, laminarin, chondroitin 6-sulfate, gellan gum, pullulan and starch. Do not produce $\mathrm{H}_{2} \mathrm{~S}$ from thiosulfate or indole from tryptophan. Capable of growth at $\mathrm{pH} 4.2-8.2$ and at $2-33{ }^{\circ} \mathrm{C} . \mathrm{NaCl}$ inhibits growth at concentrations above $1 \%$

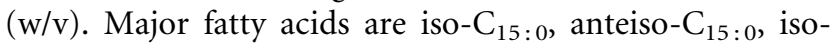
$\mathrm{C}_{17: 0} 3-\mathrm{OH}$ and summed feature 3 (iso- $\mathrm{C}_{15: 0} 2-\mathrm{OH}$ and/or $\mathrm{C}_{16: 1}(\omega 7 c)$; the quinones are MK-7 and MK- 6 . The G+C content of the DNA varies between 42.4 and $46.1 \mathrm{~mol} \%$. Member of the family Sphingobacteriaceae. Strains have been isolated from acidic wetlands, specifically Sphagnum peat bogs. The type species is Mucilaginibacter paludis.

\section{Description of Mucilaginibacter paludis sp. nov.}

Mucilaginibacter paludis (pa.lu'dis. L. gen. n. paludis of a swamp, of a marsh, of a bog).

The description is as for the genus with the following additional traits. Cells are $0.5-0.8 \mu \mathrm{m}$ wide. Colony colour varies from light pink to reddish. Utilizes D-cellobiose, Dfructose, D-galactose, sodium D-galacturonate, sodium D-gluconate, D-glucose, D-lactose, leucrose, maltose, Drhamnose, sucrose, trehalose, D-xylose, D-mannose, myoinositol and $\mathrm{N}$-acetylglucosamine. Does not utilize acetate, adonitol, arabitol, arbutin, butyrate, capronate, citrate, Darabinose, D-melezitose, D-melibiose, D-raffinose, dulcitol, fumarate, inulin, malate, mannitol, propionate, pyruvate, salicin, sorbitol, succinate or valerate. Capable of fermenting glucose and sucrose. Hydrolyses chondroitin 6-sulfate, 


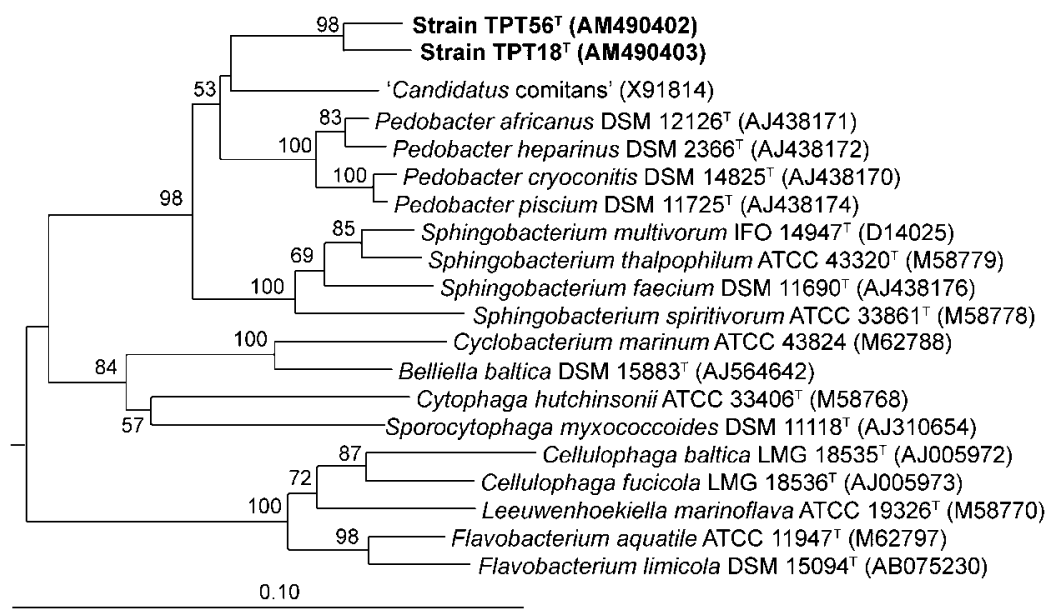

Fig. 2. $16 S$ rRNA gene-based neighbourjoining tree showing the phylogenetic positions of strains TPT18 ${ }^{\top}$ and $\mathrm{TPT}^{\mathrm{T}} 6^{\mathrm{T}}$ in relation to members of the genera Pedobacter and Sphingobacterium and some other representative members of the phylum Bacteroidetes. Bootstrap values (1000 data resamplings) $>50 \%$ are shown. The sequence of Chlorobium limicola UdG 6040 (GenBank accession no. Y10642) was used as an outgroup (not shown). Bar, 0.1 substitutions per nucleotide position.

gellan gum, laminarin, pectin, pullulan, starch and xylan but not alginate, CM-cellulose, cellulose, chitin, aesculin, fucoidan, heparin or lichenan. Produces acid from cellobiose, fructose, galactose, glucose, lactose, maltose, rhamnose, sucrose, xylose, mannose, laminarin and xylan. Optimal growth at $20-25{ }^{\circ} \mathrm{C}$ and at $\mathrm{pH}$ 6.0-6.5.

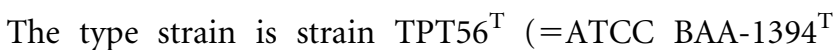
$=$ VKM B-2446 ${ }^{\mathrm{T}}$ ), which was isolated from the Sphagnum peat bog Bakchar in the Tomsk region of western Siberia.

\section{Description of Mucilaginibacter gracilis sp. nov.}

Mucilaginibacter gracilis (gra'ci.lis. L. masc. adj. gracilis slender or thin).

The description is as for the genus with the following additional traits. Cells are $0.4-0.5 \mu \mathrm{m}$ wide. Colony colour varies from creamy to yellowish or light orange. Utilizes Darabinose, D-galactose, D-glucose, D-xylose, D-lactose, maltose, D-rhamnose, D-raffinose, salicin, sucrose, trehalose, D-fructose, D-cellobiose and pyruvate but not $N$ acetylglucosamine, D-melibiose, D-melezitose, L-sorbose, acetate, butyrate, valerate, gluconate, capronate, malate, propionate, succinate, fumarate, citrate, adonitol, arabitol, arbutin, dulcitol, inulin, mannitol, myo-inositol, sorbitol, mannose or sodium D-galacturonate. Capable of fermenting glucose and sucrose. Hydrolyses chondroitin 6-sulfate, gellan gum, laminarin, pectin, pullulan, starch and xylan but not alginate, CM-cellulose, cellulose, chitin, aesculin, fucoidan, heparin or lichenan. Produces acid from Dgalactose, D-glucose, D-xylose, maltose, sucrose, trehalose, D-fructose, D-cellobiose, laminarin and xylan but not from mannose. Optimal growth at $18-22{ }^{\circ} \mathrm{C}$ and at $\mathrm{pH}$ 5.8-6.2.

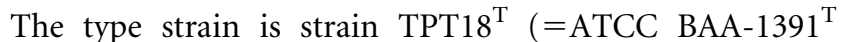
$=$ VKM B-2447 ${ }^{\mathrm{T}}$ ), which was isolated from the Sphagnum peat bog Bakchar in the Tomsk region of western Siberia.

Table 2. Major characteristics that distinguish Mucilaginibacter gen. nov. and the genera Pedobacter and Sphingobacterium

Data for Pedobacter and Sphingobacterium species were taken from Steyn et al. (1998), Shivaji et al. (2005), Vanparys et al. (2005), Hwang et al. (2005), Kim et al. (2006), Gallego et al. (2006) and Yoon et al. (2006).

\begin{tabular}{|lccc|}
\hline Characteristic & Mucilaginibacter & Pedobacter & Sphingobacterium \\
\hline Relation to oxygen & Facultatively aerobic & Strictly aerobic & Facultatively aerobic \\
Copious EPS production & + & - & - \\
L-forms of cells in old cultures & + & - & - \\
Growth at $\mathrm{pH} 4.5$ & + & - & - \\
Growth at $>1 \% \mathrm{NaCl}$ & - & + & + \\
Hydrolysis of heparin & - & + & - \\
Acid production from melibiose & - & - & + \\
Assimilation of D-melezitose & - & - & - \\
anteiso-C $15: 0$ as a major fatty acid & + & MK-7 & MK-7 \\
Quinone(s) & MK-7, MK-6 & $36-45$ & $37-44$ \\
DNA G + C content (mol\%) & $42-46$ & & \\
\hline
\end{tabular}




\section{Acknowledgements}

This research was supported by the 'Molecular and Cell Biology' programme of the Russian Academy of Sciences, the Russian Science Support Foundation and the Deutsche Forschungsgemeinschaft (436 RUS 113/543/0-4).

\section{References}

Collins, M. D. (1985). Analysis of isoprenoid quinones. Methods Microbiol 18, 329-366.

Dedysh, S. N., Pankratov, T. A., Kulichevskaya, I. S., Belova, S. E. \& Liesack, W. (2006). Phylogenetic analysis and in situ identification of bacteria community composition in an acidic Sphagnum peat bog. Appl Environ Microbiol 72, 2110-2117.

Floyd, M. M., Tang, J., Kane, M. \& Emerson, D. (2005). Captured diversity in a culture collection: case study of the geographic and habitat distribution of environmental isolates held at the American Type Culture Collection. Appl Environ Microbiol 71, 2813-2823.

Gallego, V., García, M. T. \& Ventosa, A. (2006). Pedobacter aquatilis sp. nov., isolated from drinking water, and emended description of the genus Pedobacter. Int J Syst Evol Microbiol 56, 1853-1858.

Gerhardt, P., Murray, R. G. E., Costilow, R. N., Nester, E. W., Wood, W. A., Krieg, N. R. \& Phillips, G. H. (editors) (1981). Manual of Methods for General Bacteriology. Washington, DC: American Society for Microbiology.

Hwang, C. Y., Choi, D. H. \& Cho, B. C. (2006). Pedobacter roseus sp. nov., isolated from a hypertrophic pond, and emended description of the genus Pedobacter. Int J Syst Evol Microbiol 56, 1831-1836.

Kim, K.-H., Ten, L. N., Liu, Q.-M., Im, W.-T. \& Lee, S.-T. (2006). Sphingobacterium daejeonense sp. nov., isolated from a compost sample. Int J Syst Evol Microbiol 56, 2031-2036.

Kulichevskaya, I. S., Guzev, V. S., Gorlenko, V. M., Liesack, W. \& Dedysh, S. N. (2006). Rhodoblastus sphagnicola sp. nov., a novel acidophilic purple non-sulfur bacterium from Sphagnum peat bog. Int J Syst Evol Microbiol 56, 1397-1402.

Ludwig, W., Strunk, O., Westram, R., Richter, L., Meier, H., Yadhukumar, Buchner, A., Lai, T., Steppi, S., Jobb, G. \& other authors (2004). ARB: a software environment for sequence data. Nucleic Acids Res 32, 1363-1371.

Owen, R. J., Lapage, S. P. \& Hill, L. R. (1969). Determination of base composition from melting profiles in dilute buffers. Biopolymers 7 , 503-516.

Pankratov, T. A., Kulichevskaya, I. S., Liesack, W. \& Dedysh, S. N. (2006). Isolation of aerobic, gliding, xylanolytic and laminarinolytic bacteria from acidic Sphagnum peatlands and emended description of Chitinophaga arvensicola Kämpfer et al. 2006. Int J Syst Evol Microbiol 56, 2761-2764.

Shivaji, S., Chaturvedi, P., Reddy, G. S. N. \& Suresh, K. (2005). Pedobacter himalayensis sp. nov., from the Hamta glacier located in the Himalayan mountain ranges of India. Int J Syst Evol Microbiol 55, 1083-1088.

Steyn, P. L., Segers, P., Vancanneyt, M., Sandra, P., Kersters, K. \& Joubert, J. J. (1998). Classification of heparinolytic bacteria into a new genus, Pedobacter, comprising four species: Pedobacter heparinus comb. nov., Pedobacter piscium comb. nov., Pedobacter africanus sp. nov. and Pedobacter saltans sp. nov. Proposal of the family Sphingobacteriaceae fam. nov. Int J Syst Bacteriol 48, 165-177.

Vanparys, B., Heylen, K., Lebbe, L. \& De Vos, P. (2005). Pedobacter caeni sp. nov., a novel species isolated from a nitrifying inoculum. Int J Syst Evol Microbiol 55, 1315-1318.

Weisburg, W. G., Barns, S. M., Pelletier, D. A. \& Lane, D. J. (1991). $16 \mathrm{~S}$ ribosomal DNA amplification for phylogenetic study. J Bacteriol 173, 697-703.

Yoon, J.-H., Lee, M.-H., Kang, S.-J., Park, S.-Y. \& Oh, T.-K. (2006). Pedobacter sandarakinus sp. nov., isolated from soil. Int J Syst Evol Microbiol 56, 1273-1277. 